\title{
A new approach to increasing the efficiency of the ship main engine air waste heat recovery cooling system
}

\author{
R. Radchenko ${ }^{1 凶}$, M. Pyrysunko ${ }^{2}$, M. Bogdanov ${ }^{3}, Y u$. Shcherbak $^{4}$ \\ 1 Admiral Makarov National University of Shipbuilding, Heroes of Ukraine Avenue, 9, Mykolaiv, 54002, Ukraine, \\ ${ }^{2}$ Admiral Makarov National University of Shipbuilding (Kherson branch), Ushakov Avenue, 44, Kherson, 73003, Ukraine, \\ 3 National University "Odessa Marine Acadamy", 8, Didrikhson str., Odessa, 65029, Ukraine \\ 4 Petro Mohyla Black Sea National University, 10, 68-Desantnykiv Str, Mykolayiv, 54003, Ukraine \\ $\checkmark$ e-mail: nirad50@gmail.com
}

The efficiency of integrated cooling air at the intake of Turbocharger and Scavenge air at the inlet of working cylinders of the main diesel engine of dry-cargo ship by transforming the waste heat into a cold by an Refrigerant Ejector Chiller (ECh) as the most simple in design and reliable in operation and by complex in design but more efficient Absorption Lithium-Bromide Chiller (ACh) was analyzed. A ship power plant of cogeneration type using the relatively low-grade heat of water of a heat supply system with a temperature of about $90^{\circ} \mathrm{C}$, that significantly complicates the problem of its conversion into cold were considered. Because of the insufficiently high efficiency of transformation of the heat of hot water (low coefficient of performance) as compared with steam, the resulting cooling capacity may not be enough for cooling intake air of the turbocharger and scavenge air, that raises the problem of the rational distribution of heat loads between the Turbocharger Intake Air cooling circuit (subsystem) and Scavenge air cooling circuit and the need to use chillers of various types. This takes into account the rational parameters of cooling processes of the scavenge air in the cogeneration high-temperature stage of scavenge air cooler, in the intermediate stage of traditional cooling air with seawater, and in the low-temperature stage for deep cooling of the scavenge air by using a chiller. A new approach is proposed to improve the efficiency of integrated cooling Intake Air of the turbocharger and Scavenge Air at the inlet of the working cylinders of the ship main engine of a transport ship, which consists in comparing the required cooling capacity and the corresponding heat needs during the trade route with the available heat of exhaust gases and scavenge air of the cogeneration power plant, determining the deficit and excess cooling capacity of heat utilizing cooling machines of various types, that allows to identify and realize the reserves of improving the efficiency of cooling intake air of the turbocharger and the scavenge air of the main diesel engine through the joint use of chillers of various types.

Key words: Waste Heat Recovery Chiller, Cooling, Intake Air, Scavenge Air, Exhaust Gas, Ship Main Engine

doi:

(C) The Author(s) 2019. This article is an open access publication

This work is licensed under the Creative Commons Attribution 4.0 International License (CC BY) http://creativecommons.org/licenses/by/4.0/

\section{Introduction}

The operation conditions of ship low-speed diesel engines are characterized by a significant change in the ambient temperature during the voyage and coresponding temperatures of air at the inlet of turbocharger (TC) and the scavenge air after the TC. At high temperatures of outboard seawater the scavenge-air coolers (SAC) are not able to maintain a scavenge air temperature at the low temperature level sufficient for damping elevated air temperatures at the inlet of TC and to provide the engine operation at a stable air temperature at the intake to the working cylinders, which would ensure high fuel efficiency of the engine.

According to the manufacturers of ship low-speed engines "MAN" and "Wartsila" [1-3], an increase in air temperature at the inlet of $\mathrm{TC}$ by $10{ }^{\circ} \mathrm{C}$ causes an increase in specific fuel consumption $b_{e}$ by $0.2 \ldots 0.7 \%$, and similarly, an increase in the scavenge air temperature after SAC leads to an increase in specific fuel consumption $b_{e}$ by approximately $0.5 \%$ and a corresponding decrease in the efficiency $\eta_{e}$ of engines which poses the acute problem of complex cooling of the engine cyclic air: at the inlet of $\mathrm{TC}$ and scavenge air at the inlet of the engine cylinders.

At the same time, with an increase in the temperature of ambient air and outboard water for cooling scavenge air, the heat, removed from the scavenge air and exhaust gases, increases. So it is quite expedient to utilize it with a waste heat recovery chiller to reduce the temperature of engine intake air and scavenge air at the inlet of engine cylinders. The use of low-boiling fluids (LBF) in the waste heat recovery chiller provides deep cooling of engine cyclic air.

\section{Literature Review}

A lot of investigations are devoted to development of resource and energy saving and emissions reduction technologies [4-7]. Various ways of cooling the cycle air of engines by conversion of waste heat with refrigerant Ejector Chiller (ECh) have been investigated as the most simple in design and reliable in operation so as more complex Absorption Lithium-Bromide Chiller (ACh) [8].

The cooling air systems both for intake air of the TC 
and scavenge air of low-speed engines by the conversion of the waste heat of exhaust gases and scavenge air by waste heat recovery chillers were proposed and the efficiency of this direction in marine power engineering was shown [8].

However, the problem of complex cooling of cyclic air (air at the intake of TC and scavenge air) of the low-speed engines of cogeneration type by using as a source of relatively low-grade water heat of the heat supply system (with a temperature of about $90^{\circ} \mathrm{C}$ ) is still unsolved. Because of the insufficiently high efficiency of conversion of the hot water heat compared with steam, the resulting cooling capacity may not be sufficient for complex cooling air at the engine intake air and scavenge air, that raises the problem of the rational distribution of heat loads between cooling circuits (subsystems) for chilling the engine intake and scavenge air and the need for the use of the waste heat recovery chiller of various types.

\section{Research Methodology}

The waste heat recovery refrigerant Ejector Chiller $(\mathrm{ECh})$ is the most simple in design [8]. However, the efficiency of conversion of waste heat into cold in Ejector Chiller (ECh) is relatively low: the coefficient of ECh performance $\zeta_{\mathrm{E}}=0.2 \ldots 0.3$, which requires a significant amount of heat. A coefficient of performance $\zeta=Q_{0} / Q_{\mathrm{h}}-$ is the ratio of generated cold $Q_{0}$ to the consumed heat $Q_{\mathrm{h}}$, extracted from exhaust gases, scavenge air. At the same time, the efficiency of transformation of heat into cold in quite complex Absorption Lithium-Bromide Chiller (ACh) is two to three times higher: $\zeta_{\mathrm{A}} \approx 0.7 \ldots 0.8$. It would be expedient to use the advantages of each of the chillers: deep cooling of the air to $t=7 \ldots 10^{\circ} \mathrm{C}$ in the $\mathrm{ECh}$ and high efficiency of the transformation of heat into cold in ACh $(\zeta=0.7 \ldots 0.8)$.

It is obvious that the combined use of $\mathrm{ACh}$ and $\mathrm{ECh}$ would be optimal. To do this, it is necessary to analyze the efficiency of the integrated cooling of the cyclic air of the low-speed diesel engines (intake air of the TC and the scavenge air) by transforming the waste heat of exhaust gases and scavenge air into the cold, comparing the necessary cooling capacity and the corresponding heat needs during an actual voyage with the amount of available waste heat of diesel engines (heat of exhaust gases and scavenge air), the results of which reveal a deficit or excess of the available waste heat for each of the methods for cooling the air (by using $\mathrm{ECh}$ or $\mathrm{ACh}$ ), and then reserves for additional cooling of the air (intake air or scavenge air) due to the corresponding excess waste heat.

So, at the first stage of the methodology for determining the thermal capacity of waste heat recovery chiller the comparison of the necessary cooling capacities for complex cooling of cycle air of diesel engines (simultaneously intake air of the TC and the scavenge air) and the corresponding total needs of waste heat of diesel engines with the amount of available heat of exhaust gases and scavenge air or excess of the existing waste heat for each of the methods of air cooling (using ECh or $\mathrm{ACh}$ ), and then additional reserves of cooling capacity for cooling intake air or scavenge air due to respond accordingly excess waste heat.

The efficiency of engine inlet and scavenge air cooling has been considered for the ship's low-speed diesel engine MAN B\&W 6S60MC6.1-TI with economical power output
$N_{e}=10 \mathrm{MW}$, specific fuel oil consumption (SFOC) $b_{\mathrm{e}}=$ $=169.8 \mathrm{~g} /(\mathrm{kWh})$ and air consumption $23.9 \mathrm{~kg} / \mathrm{s}$ under ISO conditions and engine load $-\mathrm{NMCR}=90 \%$. [1, 3]. To analyze the parameters of the cooling air system, as well as the characteristics of the main engine with air cooling for changeable ambient conditions the "mandieselturbo" software package was used [3].

For the 6S60MC6.1-TI engine, according to the data of the MAN company (according to the calculations by using "mandieselturbo" software package), cooling inlet air for every $10{ }^{\circ} \mathrm{C}$ results in reduction of specific fuel consumption 1.1-1.2 g/(kWh) [3].

Characteristics of the work of the ECh was chosen taking into account the features of cooling air for ship diesel engines: refrigerant $-\mathrm{R} 142 \mathrm{~b}$; boiling temperature in the evaporator-air cooler $\mathrm{t}_{0}=5{ }^{\circ} \mathrm{C}$; condensing temperature in a water cooled condenser with seawater $-\mathrm{t}_{\mathrm{c}}=25-45^{\circ} \mathrm{C}$; boiling temperature in the generator $-t_{g}=90{ }^{\circ} \mathrm{C}$.

Thus, for comparative analysis the following values of coefficient of performance were accepted: $\zeta=0.7$ for $\mathrm{Ab}$ sorption Lithium-Bromide Chiller (ACh) and $\zeta=0.2$ for Ejector Chiller (ECh) at boiling temperature of the refrigerant $\mathrm{R} 142 \mathrm{~b}$ in the evaporator $\mathrm{t}_{0}=5^{\circ} \mathrm{C}$ and in the generator $\mathrm{t}_{\mathrm{g}}=90^{\circ} \mathrm{C}$.

The calculation of the characteristics of the engine with cyclic air cooling was carried out on the operating mode during the voyage of the dry-cargo ship on the route Odessa-Yokogama. The changes in ambient air temperature $t_{a}$, temperature of outboard water $t_{w}$, ambient air absolute humidity $d_{a}$ and relative humidity $\varphi_{a}$ during the trade route are presented in fig. 1 .

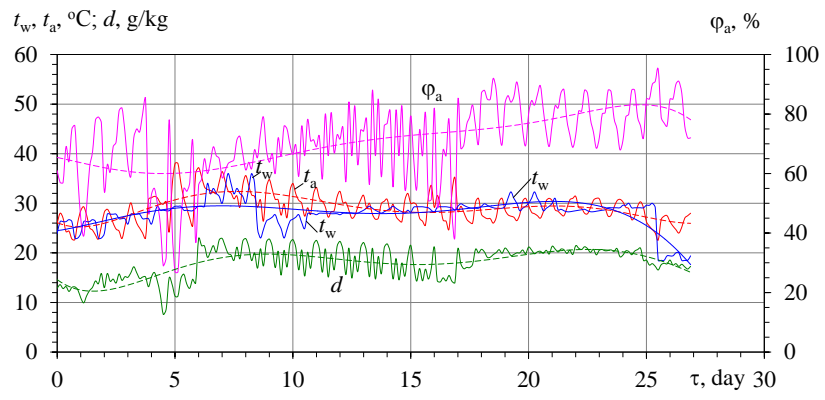

Figure 1 - The changes in ambient air temperature $t_{a}$, temperature of outboard water $t_{w}$, ambient air absolute humidity air $d_{a}$ and relative humidity $\varphi_{a}$ during the trade route Odessa-Yokogama

When climatic conditions change during the trade route, the heat load of the cooling system changes, that is, cooling capacity $Q_{0}$ is necessary for cooling the air, as well as the corresponding heat consumption $Q_{\mathrm{h}}$, transformed into cold in waste heat recovery chiller: $Q_{\mathrm{h}}=Q_{0} / \zeta$.

Characteristics of the ECh performance was chosen taking into account the features of the design and use of air pre-cooling for ship diesel engines: refrigerant $-\mathrm{R} 142 \mathrm{~b}$; boiling temperature in the evaporator-air cooler $\mathrm{t}_{0}=5{ }^{\circ} \mathrm{C}$; condensing temperature in a water cooled condenser with seawater $-\mathrm{t}_{\mathrm{c}}=25-45{ }^{\circ} \mathrm{C}$; boiling temperature in the generator $-\mathrm{t}_{\mathrm{g}}=90^{\circ} \mathrm{C}$.

Thus, for comparative analysis the following values of coefficient of performance are accepted: $\zeta=0.7$ for Ab- 
sorption Lithium-Bromide Chiller (ACh) and $\zeta=0.2$ for Ejector Chiller (ECh).

\section{Results}

The cooling capacity $Q_{0.15}$, required for cooling the Intake Air of the engine, was calculated based on the decrease in its temperature from the current temperature in the engine room $t_{\mathrm{a} 1} \quad\left(t_{\mathrm{a} 1}=t_{\mathrm{a}}+10{ }^{\circ} \mathrm{C}\right)$ to $t_{\mathrm{a} 2}=15^{\circ} \mathrm{C}$ by the value $\Delta t_{\mathrm{a} 15}$. The available cooling capacity was calculated as $Q_{0(0.7)}$ - during the transformation of the exhaust gas heat $Q_{\mathrm{h}}$ to cold in $\operatorname{ACh}\left(Q_{0}=Q_{\mathrm{h}} \cdot \zeta\right.$ at $\left.\zeta=0.7\right)$ and as $Q_{0(0.2)}$ - during the transformation of exhaust gas heat $Q_{\mathrm{h}}$ in the ECh (at $\zeta=0.2$ ). The heat required for cooling the air at the engine inlet to the temperature $t_{\mathrm{a} 2}=15^{\circ} \mathrm{C}$ in ACh was calculated as $Q_{\mathrm{h} .15(0.7)}=Q_{0.15} / \zeta \quad$ (at $\zeta=0.7$ ), and in ECh - as $Q_{\mathrm{h} .15(0.2)}=Q_{0.15} / \zeta \quad$ at $\left.\zeta=0.2\right)$.
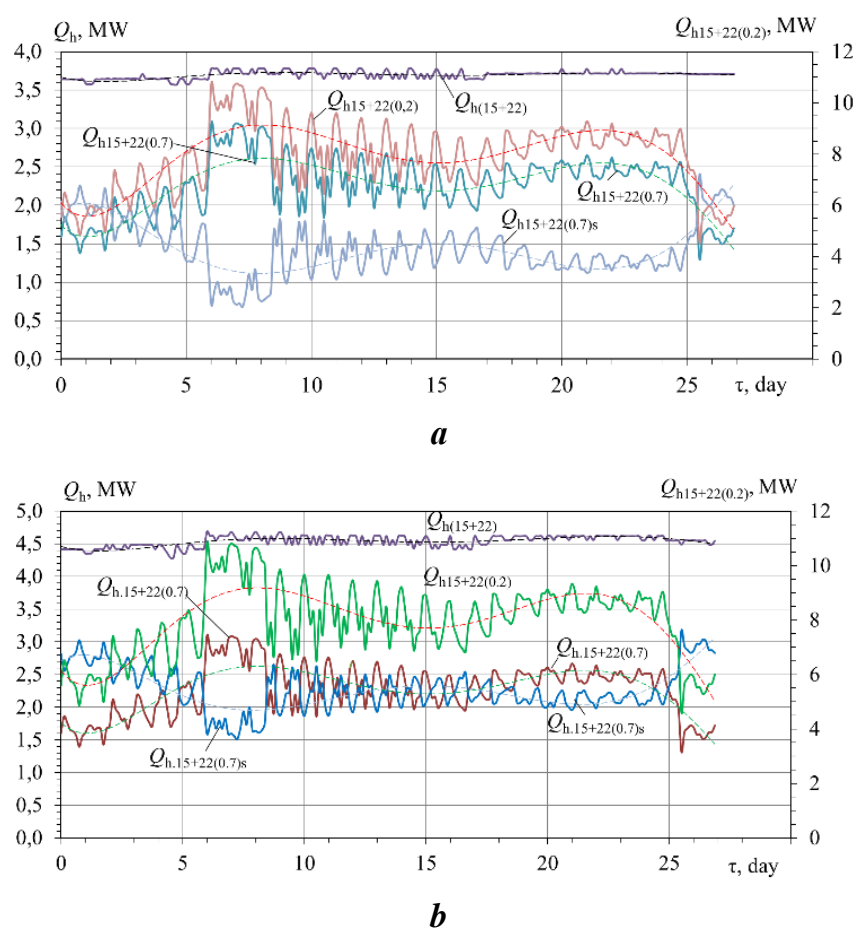

Figure 2 - The current values of available heat of exhaust gases and scavenge air $Q_{h(15+22)}$, heat required for cooling the intake air to $t_{a 2}=15^{\circ} \mathrm{C}$ and scavenge air in the $S A C_{L T}$ to $t_{a 2}=22^{\circ} \mathrm{C}$ in the ECh $Q_{h 15+22(0.2)}$ at $\zeta=0.2(E C h$ at $t_{h}=90^{\circ} \mathrm{C}$ and $t_{0}=5$ ), in the ACh $Q_{h 15+22(0.7)}$ at $\zeta=0.7$, surplus (excess) heat available for ACh $Q_{h .15+22(0.7) s}$ and heat deficit for ECh $Q_{h 15+22(0.2) d}$ during the voyage OdessaYokohama at scavenge air temperatures at the outlet of the $S A C_{H T} t_{h 2}: \boldsymbol{a}-t_{h 2}=140^{\circ} \mathrm{C} ; \boldsymbol{b}-t_{h 2}=110^{\circ} \mathrm{C}$

As it is seen, the value of the available (existing) heat of exhaust gases $Q_{\mathrm{h} .15}$ and scavenge air $Q_{\mathrm{h} 22}$ are close to each other $Q_{\mathrm{h} 22} \approx Q_{\mathrm{h} 15} \approx 2.2 \ldots 2.6 \mathrm{MW}$ and their total amount $Q_{\mathrm{h}(15+22)} \approx 4.5 \ldots .5 .0 \mathrm{MW}$ is almost twice higher the heat $Q_{\mathrm{h} 15+22(0.7)}$, required for cooling the intake air to a temperature $t_{\mathrm{a} 2}=15^{\circ} \mathrm{C}$ and scavenge air in the $\mathrm{SAC}_{\mathrm{LT}}$ to a temperature $t_{\mathrm{a} 2}=22{ }^{\circ} \mathrm{C}$ in the ACh with a coefficient of performance $\zeta=0.7$, as evidenced by a significant excess of the available heat $Q_{\mathrm{h} 15+22(0.7) \mathrm{s}}=Q_{\mathrm{h}(15+22)}-Q_{\mathrm{h} 15+22(0.7)} \approx$ $\approx 3,5 \ldots 4,5 \mathrm{MW}$ for $\mathrm{ACh}$.
At the same time, the total amount of available heat of exhaust gases and scavenge air $Q_{\mathrm{h}(15+22)}$ is almost half the heat $Q_{\mathrm{h} 15+22(0.2)} \approx 9 \mathrm{MW}$, necessary for cooling the intake air to $t_{\mathrm{a} 2}=15{ }^{\circ} \mathrm{C}$ and Scavenge Air in a SAC $\mathrm{HT}_{\mathrm{H}}$ to $t_{\mathrm{a} 2}=22^{\circ} \mathrm{C}$ in a ECh with a coefficient of performance $\zeta=0.2$, as evidenced by a significant deficit of heat $Q_{\mathrm{h} 15+22(0.2) \mathrm{d}}=$ $=Q_{\mathrm{h} 15+22(0.2)}-Q_{\mathrm{h}(15+22)} \approx 3 \ldots 4 \mathrm{MW}$ for the ECh (fig. 3).
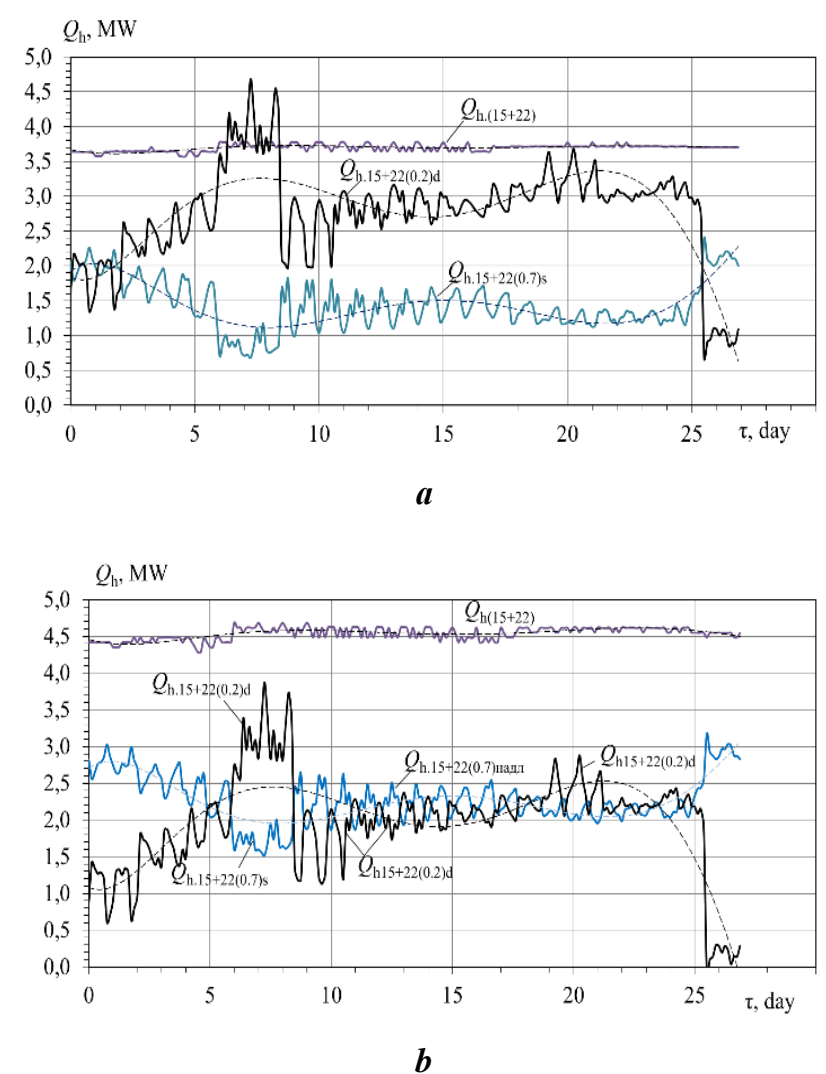

Figure 3 - The current values of the total amount of available heat of exhaust gases and scavenge air $Q_{h(15+22)}$, heat required for cooling the intake air to $t_{a 2}=15^{\circ} \mathrm{C}$ and scavenge air in the $S A C_{L T}$ to $t_{a 2}=22^{\circ} \mathrm{C}$ in the ECh $Q_{h 15+22(0,2)}$ at $\zeta=0.2\left(E C h\right.$ at $t_{h}=90^{\circ} \mathrm{C}$ and $\left.t_{0}=5\right)$, surplus heat available for ACh $Q_{h .15+22(0.7) s}$ and heat deficit for ECh $Q_{h 15+22(0.2) d}$ during the voyage Odessa-Yokohama at scavenge air temperatures at the outlet of the $S A C_{H T} t_{h 2}$ : $\boldsymbol{a}-t_{h 2}=140{ }^{\circ} \mathrm{C} ; \boldsymbol{b}-t_{h 2}=110^{\circ} \mathrm{C}$

The closeness of heat deficit values for ECh $Q_{\mathrm{h} 15+22(0.2) \mathrm{d}}$ and excess available heat which is more then required for ACh $Q_{\mathrm{h} .15+22(0.7) \mathrm{s}}$ indicates the possibility of their mutual compensation through the joint use of ACh as an effective transformer of heat to cold $(\zeta=0.7)$, however, at less depth of air cooling (up to $t_{\mathrm{a} 2}=15^{\circ} \mathrm{C}$ ), and less effective ECh $(\zeta=0.2 \ldots 0.3)$ for deeper cooling of the air (to the minimum potential $t_{\mathrm{a} 2}=10^{\circ} \mathrm{C}$ and even lower).

The values of the available total cooling capacity, which can be obtained due to the total amount of heat of exhaust gases $Q_{\mathrm{h}(15+22)}$ in a ACh $Q_{0.15+22(0.7)}(\zeta=0.7)$ and in ECh $Q_{0.15+22(0.2)}(\zeta=0.2)$ as well as the total cooling capacity $Q_{0.15+22}$, necessary for cooling intake air of the TC to $t_{\mathrm{a} 2}=$ $=15{ }^{\circ} \mathrm{C}$ and the scavenge air to $t_{\mathrm{a} 2}=22{ }^{\circ} \mathrm{C}$ with the total decrease in air temperature by the value of $\Delta \mathrm{t}_{\mathrm{a} 15+22}=\Delta \mathrm{t}_{\mathrm{a} 15}+$ $+\Delta \mathrm{t}_{\mathrm{a} 22}$ according to the climatic conditions on the trade route (fig. 4.). 

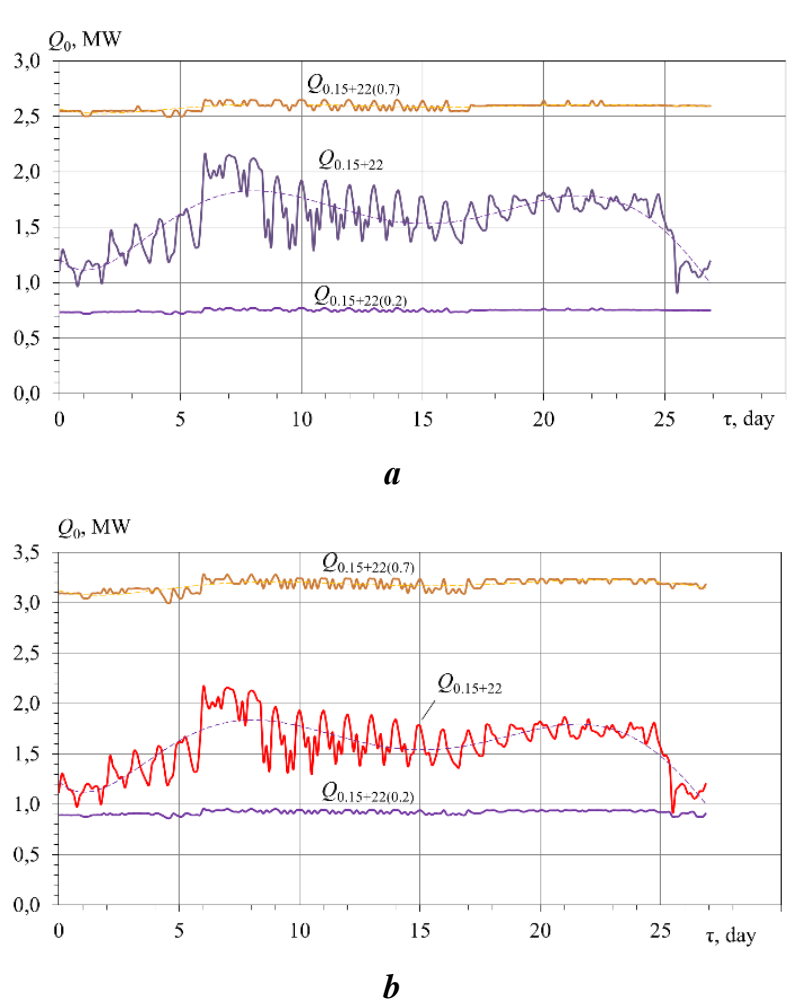

Figure 4 - The values of the available cooling capacity, which can be obtained by using the total amount of heat of exhaust gases $Q_{h(15+22)}$ in the ACh $Q_{0.15+22(0.7)}(\zeta=0.7)$ and in the ECh $Q_{0.15+22(0.2)}(\zeta=0.2)$, as well as the total cooling capacity $Q_{0.15+22}$, necessary for cooling the intake air to $t_{a 2}=15^{\circ} \mathrm{C}$ and scavenge air to $t_{a 2}=22^{\circ} \mathrm{C}$ at scavenge air temperatures at the outlet of the $S A C_{H T} t_{h 2}: \boldsymbol{a}-t_{h 2}=$ $140{ }^{\circ} \mathrm{C} ; \boldsymbol{b}-t_{h 2}=110^{\circ} \mathrm{C}$

The values of ECh cooling capacity deficit $Q_{0.15+22(0.2) \mathrm{d}}=$ $\mathrm{Q}_{0.15+22}-\mathrm{Q}_{0.15+22(0.2)}$ and the ACh surplus (excess) cooling capacity $Q_{0.15+22(0.7) \mathrm{s}}=\mathrm{Q}_{0.15+22(0.7)}-\mathrm{Q}_{0.15+22}$ during the voyage Odessa-Yokohama are presented in fig. 5.

It should be noted that correlation between the ECh cooling capacity deficit $Q_{0.15+22(0,2) \mathrm{d}}=\mathrm{Q}_{0.15+22}$ $\mathrm{Q}_{0.15+22(0.2)}$ and the ACh surplus (excess) cooling capacity $Q_{0.15+22(0.7) \mathrm{s}}=\mathrm{Q}_{0.15+22(0.7)}-\mathrm{Q}_{0.15+22}$ during the voyage (fig. 5) can be changed by using the surplus cooling capacity of ACh $Q_{0.15+22(0.7) s}$ (compared with the total cooling capacity $Q_{0.15+22}$, necessary for cooling intake air to the temperature $t_{\mathrm{a} 2}=15^{\circ} \mathrm{C}$ and scavenge air to $t_{\mathrm{a} 2}=22^{\circ} \mathrm{C}$ ) for completely eliminating the ECh cooling capacity deficit $Q_{0.15+22(0.2) \mathrm{d}}$. It can be fulfilled through partial replacement of the ECh cooling capacity with the ACh cooling capacity by using the ECh only for cooling the engine intake air or scavenge air.

By rational redistribution of heat flows of waste heat (exhaust gases and scavenge air) between various types of waste heat recovery chillers (ECh and $\mathrm{ACh}$ ), and the cooling capacity obtained by the chillers between the engine intake air and scavenge air cooling, it is possible to ensure simultaneous complex cooling of the cyclic air of the engine and obtain almost double effect in the form of reduced fuel consumption. In this case, the redistribution of heat flows during the actual conversion of waste heat into cold - the ratio of generated cooling capacity $Q_{0}$ and heat consumption for its production $Q_{\mathrm{h}}$ - is determined by the coefficient of performance $\zeta=Q_{0} / Q_{\mathrm{h}}$, that is, by the type of waste heat recovery chiller.
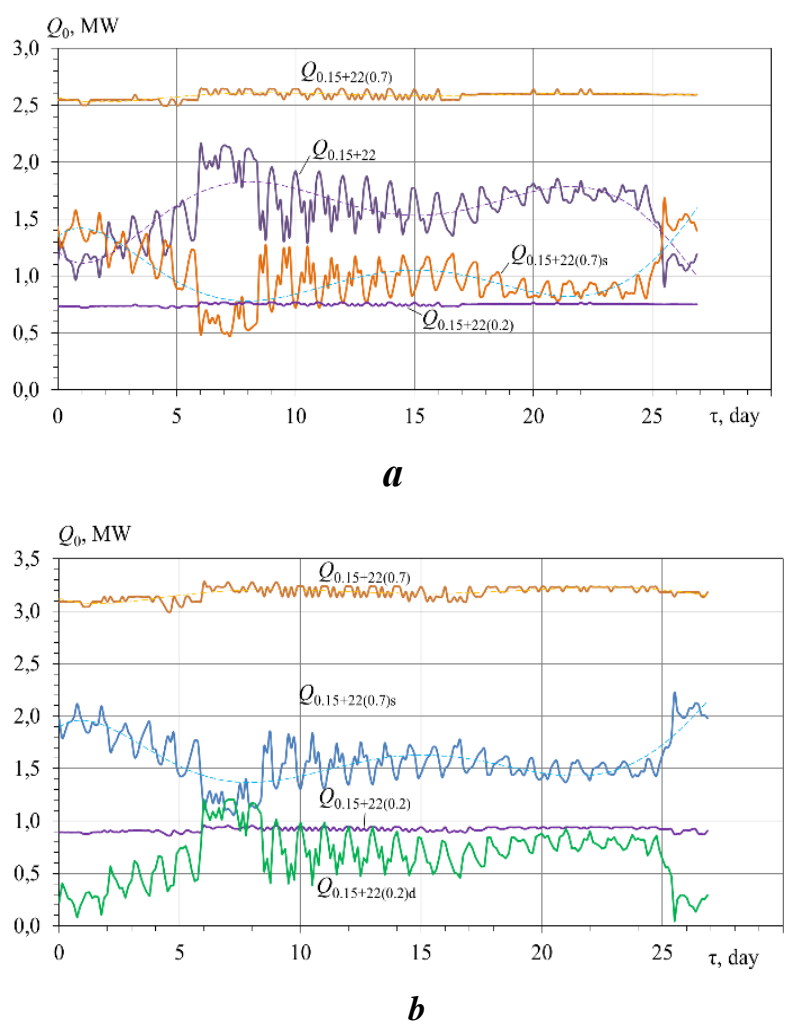

Figure 5 - The values of the available total cooling capacity, which can be obtained by using the heat of scavenge air and exhaust gases $Q_{h(15+22)}$ in the ACh $Q_{0.15+22(0.7)}(\zeta=0.7)$ and in the ECh $Q_{0.15+22(0.2)}(\zeta=0.2)$, cooling capacity deficit of the ECh $Q_{0.15+22(0.2) d}=Q_{0.15+22}-$ $Q_{0.15+22(0.2)}$ and surplus cooling capacity of the ACh $Q_{0.15+22(0.7) s}=Q_{0.15+22(0.7)}-Q_{0.15+22}$ during the voyage Odessa-Yokohama: $\boldsymbol{a}-t_{h 2}=140{ }^{\circ} \mathrm{C} ; \boldsymbol{b}-t_{h 2}=110^{\circ} \mathrm{C}$

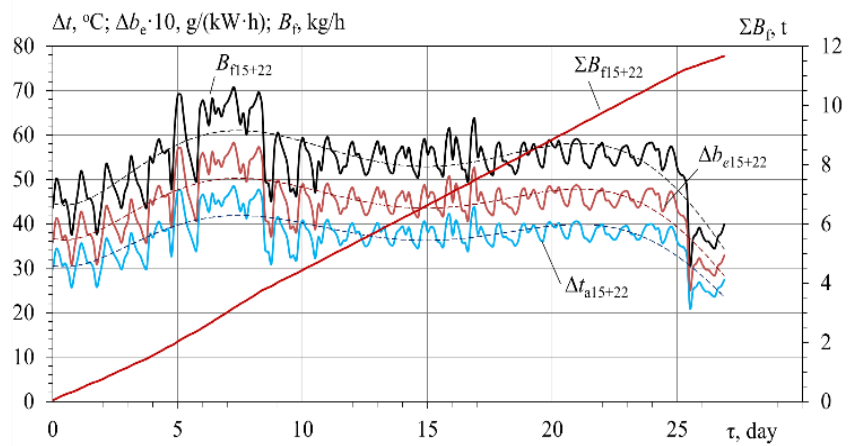

Figure 6 - The current values of the full reduction in specific $\Delta b_{e .15+22}$ and hourly $B_{f .15+22}$ fuel consumption due to simultaneously cooling the air at the intake of the TC to the temperature $t_{a 2}=15^{\circ} \mathrm{C}$ and scavenge air to $t_{a 2}=22{ }^{\circ} \mathrm{C}$ with a summerised decrease in the cyclic air temperature by $\Delta t_{a 15+22}$ in $A C h$ and ECh and the corresponding accumulated total reduction of fuel consumption $\sum B_{f .15+22}$ of the low-speed engine 6S60MC6.1-TI during the voyage for the climatic conditions on the trade route Odessa-Yokohama 
The aggregate effect of complex cooling engine intake air to $t_{\mathrm{a} 2}=15^{\circ} \mathrm{C}$ and scavenge air to $t_{\mathrm{a} 2}=22^{\circ} \mathrm{C}$ with a summerised decrease in the cyclic air temperature by $\Delta t_{\mathrm{a} 15+22(0.2)}$ can be estimated by the current full reduction of specific $\Delta b_{e 15+22}$ and hourly $B_{\mathrm{f} 15+22}$ fuel consumption and corresponding accumulated total reduction of fuel consumption $\sum \mathrm{B}_{\mathrm{f} .15+22}$ of the low-speed engine 6S60MC6.1-TI during the voyage for the climatic conditions on the trade route Odessa-Yokohama in fig. 6 .

As can be seen, the joint cooling of the intake air of the TC to the temperature $t_{\mathrm{a} 2}=15^{\circ} \mathrm{C}$ and the scavenge air to $t_{\mathrm{a} 2}=15^{\circ} \mathrm{C}$ ensures the reduction of the specific fuel consumption of the low-speed engine 6S60MC6.1-TI by the value $\Delta b_{\mathrm{e} .15+22}=4.0 \ldots 4.5 \mathrm{~g} /(\mathrm{kW} \cdot \mathrm{h})$ and hourly consumption $\mathrm{B}_{\mathrm{f} .15+22}=50 \ldots 60 \mathrm{~kg} / \mathrm{h}$ and total fuel consumption $\sum \mathrm{B}_{\mathrm{f} .15+22} \approx 11 \mathrm{t}$ during the trade route OdessaYokohama.

\section{Conclusions}

The efficiency of joint cooling the Intake Air of the turbocharger and Scavenge Air at the inlet of the working cylinders of the Ship Main Engine of the transport ship by the conversion of the waste heat by an Ejector Chiller and an Absorption Lithium-Bromide Chiller was analyzed. As a source of heat for chillers, water from the heat supply system, obtained from the heat of the Scavenge Air and engine exhaust gases, is used. The reserves to improve the cooling efficiency of the main diesel engine cyclic air through using the chillers of various types were reveiled. A new approach to improving the efficiency of cyclic air cooling of the Main Engine of a transport ship has been proposed.

\section{References}

1. MAN Diesel \& Turbo (2018), MAN B\&W Two-stroke Marine Engines. Emission Project Guide [Online], available at: https://marine.man-es.com/applications /projectguides/2stroke/content/special_pg/7020-0145-09_ uk.pdf (Accessed 9 October 2018)

2. Wartsila (2017), Wärtsilä Environmental Product Guide, [Online], available at: https://cdn.wartsila.com/ docs/default-source/product-files/egc/product-guide-o-envenvironmental-solutions.pdf (April 2017).

3. MAN Diesel Turbo (2019), "CEAS Engine Calculations" [Online], available at: https://marine.manes.com/two-stroke/ceas.

4. N. Bent (2009), 8500 TEU Container Ship Green Ship of the Future Concept study, Odense Steel Shipyard Ltd, [Online], available at: https://www. dendanskemaritimefond.dk/wp-content/uploads/2016/04/Green-Ship-

Report-Containership-4Dec09. pdf (Accessed 4 December 2009).

5. Radchenko R. N. and Pyrysunko M. A. (2018) "Method of recycling exhaust gases of marine diesel engines to reduce their toxicity", Refrigeration engineering and technology, 54 (4), 11-16.

DOI https://doi.org/10.15673/ret.v54i4.1215

6. Radchenko R. N. and Pyrysunko M. A. (2018) "Decreasing emissions of nitrogen oxides with exhaust gases of marine diesel engines", Aerospace Engineering and Technology, 149 (5), $36-41$.

DOI: $10.32620 / \mathrm{aktt} .2018 .5 .06$

7. Pyrysunko M. A. (2018), "Analyzing the methods of reduction of toxic emissions from marine en-gines through exhaust gas recirculation", Refrigeration engineering and technology, 54 (6), 39-44.

DOI https://doi.org/10.15673/ret.v54i6.1259

8. Radchenko N. I., Stahel A. A. and Sirota A. A. and Scherbak Yu. G. (2016), "Cooling the low-speed diesel scavenge air using its heat", Aerospace Engineering and Technology, 138 (3), 94-98. [Online], available at: http://nbuv.gov.ua/UJRN/Kiem_2016_1_10

\title{
Новий підхід до підвищення ефективності тепловикористовуючої системи охололодження повітря суднового головного двигуна
}

\author{
Р. М. Радченко ${ }^{1}$, М. А. Пирисунько ${ }^{2}$, М. С. Богданов ${ }^{3}$ Ю. Г. Щербак \\ 1 Національний університет кораблебудування ім. адм. Макарова, просп. Героїв України, 9, Миколаїв, 54002, \\ Україна \\ ${ }^{2}$ Національний університет кораблебудування ім. адм. Макарова, Херсонська філія, пр. Ушакова, 44, м. Херсон, \\ 73003, Україна \\ 3 Національний університет "Одеська морська академія", вул. Дідріхсона, 8, Одеса, 65029, Україна \\ 4 Чорноморський національний університет ім. П. Могили, вул. 68 Десантників, 10, Миколаїв, 54003, Україна
}

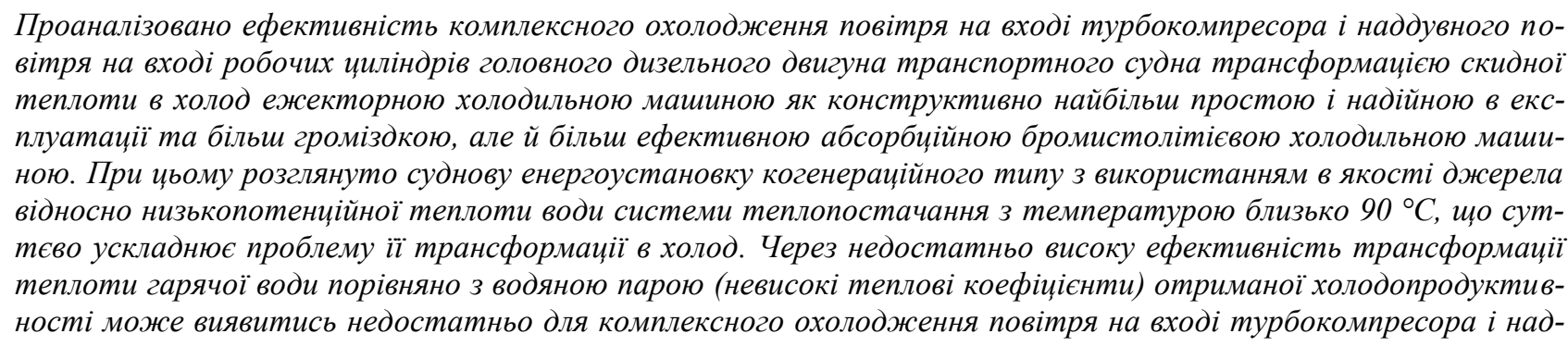


дувного повітря, щуо гостро ставить питання раціонального розподілу теплових навантажень між контурами (підсистемами) охолодження повітря на вході турбокомпресора і наддувного повітря двигуна $і$ необхідність застосування холодильних машин різного типу. При изьому враховано раціональні параметри процесів охолодження наддувного повітря в когенераційному високотемпературному ступені, проміжному ступені традииійного охолодження забортною водою та низькотемпературному ступені глибокого охолодження наддувного повітря тепловикористовуючою холодильною машиною. Запропоновано новий підхід до підвищення ефективності комплексного охолодження повітря на вході турбокомпресора і наддувного повітря на вході робочих ичиліндрів головного двигуна транспортного судна, який полягає у зіставленні необхідних витрат холодопродуктивності і відповідних потреб теплоти упродовж рейсу з наявною теплотою випускних газів $i$ наддувного повітря когенераційної енергоустановки, визначенні дефіциту і надлишку холодопродуктивності тепловикористовуючих холодильних машин різного типу, щь дозволяє виявити і реалузувати резерви підвищення ефективності охолодження повітря на вході турбокомпресора і наддувного повітря на вході головного дизельного двигуна шляхом сумісного застосування холодильних машин різного типу.

Ключові слова: Тепловикористовуюча холодильна машина, Повітря на вході, Наддувне повітря, Випускні гази, Головний судновий двигун

\section{Література}

1. MAN Diesel \& Turbo (2018), MAN B\&W Two-stroke Marine Engines. Emission Project Guide [Online], available at: https://marine.man-es.com/applications /projectguides/2stroke/content/special_pg/70200145-09_uk.pdf (Accessed 9 October 2018).

2. Wartsila (2017), Wärtsilä Environmental Product Guide, [Online], available at: https://cdn.wartsila.com/ docs/default-source/product-files/egc/product-guide-o-envenvironmental-solutions.pdf (April 2017).

3. MAN Diesel Turbo (2019), "CEAS Engine Calculations" [Online], available at: https://marine.manes.com/two-stroke/ceas.

4. N. Bent (2009), 8500 TEU Container Ship Green Ship of the Future Concept study, Odense Steel Shipyard Ltd, [Online], available at: https://www. dendanskemaritimefond.dk/wp-content/uploads/2016/04/Green-Ship-

Report-Containership-4Dec09. pdf (Accessed 4 December 2009).

5. Радченко Р.М., Пирисунько М.А. (2018), "Метод рециркуляції відпрацьованих газів суднових дизелів для зменшення їх токсичності", Холодильна техніка та технологія, № 4 (54), ст. 11-16.

DOI https://doi.org/10.15673/ret.v54i4.1215

6. Радченко Р.М., Пирисунько М.А. (2018), "Зменшення викидів оксидів азоту з відпрацьованими газами суднових дизелів", Авиационно-космическая техника и технология, № 5(149), ст. $36-41$.

DOI: $10.32620 / \mathrm{aktt} .2018 .5 .06$

7. Пирисунько М. А. (2018), "Аналіз способів зменшення шкідливих викидів суднових двигунів рециркуляцією відпрацьованих газі", Холодильна техніка та технологія, № 6 (54), ст. 39-44.

DOI https://doi.org/10.15673/ret.v54i6.1259

8. Радченко Н.И., Стахель А., Богданов Н.С., Щербак Ю.Г. (2017), "Охлаждение наддувочного воздуха малооборотного дизеля использованием его тепла", Авиачионно-космическая техника и технология, № 3 (138). ст. 94-98. URL: http://nbuv.gov.ua/UJRN/Kiem_ 2016_1_10

Отримана в редакції 10.01.2019, прийнята до друку 05.02.2019 